\title{
EXTERNAL CHARACTERISTICS USEFUL TO DISCRIMINATE THE SEXES OF THE BEETLE Costalimaita lurida (LEFÈVRE 1891) (COLEOPTERA: CHRYSOMELIDAE, EUMOLPINAE)
}

\author{
Alexandre Arnhold ${ }^{1}$, Jacques Hubert Charles Delabie ${ }^{2}$, Dinarte Gonçalves ${ }^{3}$ \\ ${ }^{1}$ Universidade Federal do Sul da Bahia (UFSB). E-mail: alexarnhold@ gmail.com \\ ${ }^{2}$ Centro de Pesquisa do Cacau. E-mail: jacques.delabie@ gmail.com \\ ${ }^{3}$ Universidade do Vale do Taquari (UNIVATES). E-mail: dinartegoncalves@ gmail.com
}

\section{ABSTRACT}

The aim of this study was to identify external morphological characteristics allowing sexual differentiation of imagos of the chrysomelid Costalimaita lurida, the most damaging defoliant beetle reported for eucalyptus in Brazil. A study of the external morphological characteristics of this beetle, (such as the shape of abdominal urosternites, antennas, presence of tufts and body dimensions) was carried out in 25 adults per sex that were later dissected for gender confirmation. The median length and the pronotum width as well as the sum of the elytra base widths showed significant differences between males and females. Other differences were observed on the abdominal segments of $C$. lurida, and the dimorphism of the urosternites can be used for the sexing of males and females. Females also present a statistically larger average size than males.

Keywords: Morphology, leaf beetle, morphometry

\section{CARACTERÍSTICAS EXTERNAS ÚTEIS PARA DISCRIMINAR OS SEXOS DO BESOURO Costalimaita lurida (LEFÈVRE 1891) (COLEOPTERA: CHRYSOMELIDAE, EUMOLPINAE)}

\section{RESUMO}

O objetivo deste estudo foi identificar caracteres morfológicos externos que permitem a diferenciação sexual das imagos do crisomelídeo Costalimaita lurida, o besouro mais danoso ao cultivo do eucalipto no Brasil. Um estudo das características morfológicas externas deste besouro, como a forma dos urosternitos abdominais, antenas, presença de tufos de pelos e dimensões corporais, foi realizado em 25 adultos de cada sexo que foram posteriormente dissecados para confirmação do seu gênero. O comprimento mediano e a largura do pronoto, bem como a soma das larguras das bases dos élitros, mostraram diferenças significativas entre machos e fêmeas. Outras 84 
diferenças foram observadas nos segmentos abdominais de $C$. lurida, e o dimorfismo dos urosternitos pode ser usado para a sexagem de machos e fêmeas. As fêmeas também apresentam tamanho médio estatisticamente maior que o dos machos.

Palavras-chave: Morfologia, besouro, morfometria

\section{INTRODUCTION}

Economically phytophagous insects are especially important to agroforestry in Brazil, especially when populations reach their damage threshold, which occurs rather frequently, especially in monocultures. The lack of adequate management is often due to a poor basic biological knowledge on these insects and can induce to the misuse of pesticides, causing deleterious damages to the environment.

Among the insects of economic importance for agroforestry in Brazil, the leaf beetles (Chrysomelidae) are generally little known in relation to many of their biological aspects. The Eumolpinae Costalimaita ferruginea (Fabricius, 1801), is considered the most damaging defoliant beetle of eucalyptus in Brazil (ANJOS \& MAJER, 2003). This species has also been reported injuring Citrus in the state of Roraima, Brazil (MARSARO-JÚNIOR et al., 2006).

The leaf beetle Costalimaita lurida (Lefèvre 1891) (Figure 1) caught our attention as it emerged several times in the form of population outbreaks, causing great damages to eucalyptus plantations and other myrtaceous cultivars in some Brazilian states (ARNHOLD \& GONÇALVES, 2010; MAFIA et al., 2014). However little is known about its behavioral characteristics or ecology. To address behavioral studies, it is essential to identify first the gender of the individuals without damaging them, which requires rapid sexing methods with a minimal manipulation. Studies that seek the sexual differentiation of beetles especially the Chrysomelidae family, focus on abdominal characteristics, mainly on urosternites (SALT, 1928; PELLETIER, 1993; FERNANDES et al., 2005), since gender differences can be easily seen. 


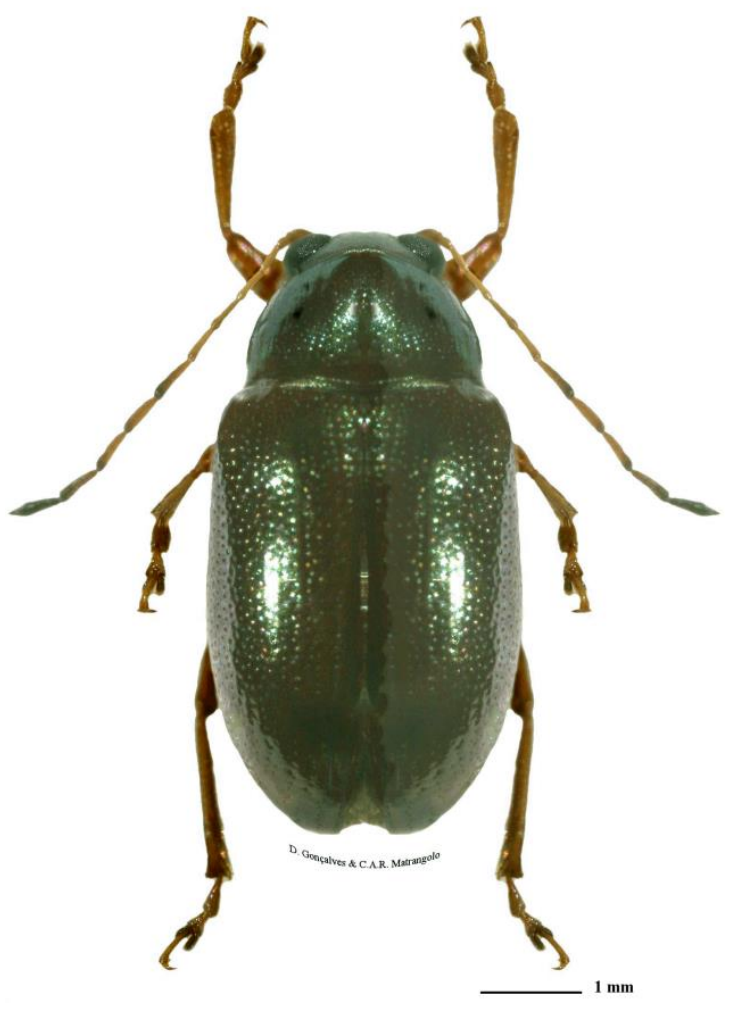

Figure 1: Chrysomelidae Costalimaita lurida (Lefèvre). Photo D. Gonçalves and C. Matrangolo.

Studies on biological aspects are especially important for warranting the success of the control of these insects. The differentiation between males and females is important information in integrated management of pests (VILELA \& DELLA LUCIA, 2001), for example, when mass sterilization is the main purpose or aiming to identify which sex releases sexual pheromone (BUTT \& CANTU, 1962; MELLINI, 1973). It can also be used in studies of sex ratio, mating and oviposition behaviors (WEBER, 1976). The aim of this study was to identify external morphological characteristics that allow the sexing of imagos of the beetle $C$. lurida without needing insect dissection.

\section{MATERIALS AND METHODS}

Individuals of $C$. lurida were collected thanks to an entomological net in an eucalyptus plantation at Bocaiúva, state of Minas Gerais, Brazil, in September, 2006. The insects were then fixed in ethanol and a series was mounted for entomological purposes. Vouchers of the biological material were deposited in the collections of the Laboratory of Entomology of the Universidade 
Federal de Viçosa (UFV) and of Dr. R. Wills Flowers (Florida A \& M University, Tallahasse, USA) who also confirmed the species identification.

The laboratory study was carried out at the Laboratory of Integrated Pest Management of UFV. The analysis of the external morphological characteristics of $C$. lurida was performed on 25 adult insects of each sex, under stereoscopic microscope with a 40x magnification. The sexual identity of each one was confirmed by means of dissection of ovaries and aedeagus. We sought to identify external morphological characteristics that allowed differentiation of the beetle sex, such as the shape of abdominal urosternites, tufts of hairs (SALT, 1928), antennae (BARTLET et al., 1999) and some dimensions of the body (FOX et al.,2003). For the morphological study, the sizes of chosen characteristics were measured, such as average length, largest pronotum width and sum of the widths of the elytra base as well for males as for females.

\section{RESULTS AND DISCUSSION}

Imagos of $C$. lurida possess distinctly five visible urosternites, with the shapes of the first, second and fifth ones differing between males (Fig. 2A) and females (Fig. 2B). In males, the first and second segments present a medial and deep longitudinal notch, with tufts of hairs on their inner margins. In females, these characteristics are absent. On the fifth urosternite, the males show protruding and slightly rounded apex margins, with the median portion serrated and flat, while the females do not present these characteristics, having the apex of the fifth urosternite more acute with its internal margin presenting a "M"-shape with sparse hairs.
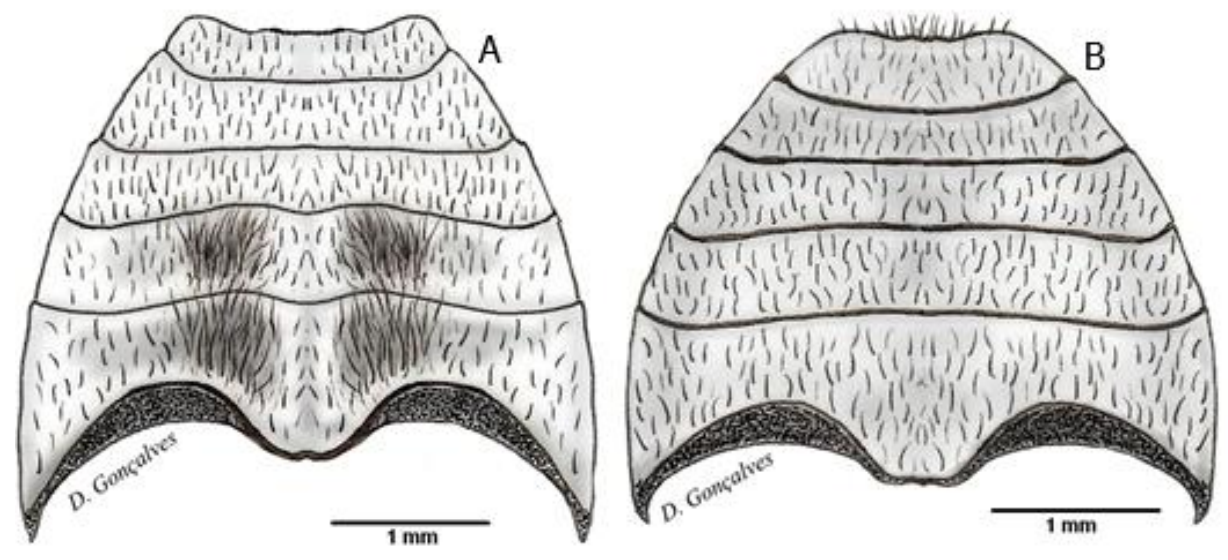

Figure 2: Abdominal characterization of Costalimaita lurida (Lefèvre) in ventral view. Male (A) and Female (B). Illustration D. Gonçalves. 
The average width of pronotum and the sum of the widths of the elytra bases of $C$. lurida showed significant differences between males and females (Analysis of Variance, $\mathrm{p}<0.05$, Table 1). The mean of the females was statistically broader than that of the males.

Table 1. Size measurements of chosen characteristics in C. lurida (mm).

\begin{tabular}{|c|c|c|c|c|c|}
\hline \multirow{2}{*}{\multicolumn{2}{|c|}{$\begin{array}{l}\text { Average } \\
\text { Pronotum length }\end{array}$}} & \multirow{2}{*}{\multicolumn{2}{|c|}{$\begin{array}{l}\text { Average } \\
\text { Pronotum width }\end{array}$}} & \multirow{2}{*}{\multicolumn{2}{|c|}{$\begin{array}{l}\text { Average } \\
\text { Elytra base width }\end{array}$}} \\
\hline & & & & & \\
\hline Males & Females & Males & Females & Males & Females \\
\hline $1,3 \pm 0,02 \mathrm{~A}$ & $1,3 \pm 0,01 \mathrm{~A}$ & $2,2 \pm 0,02 \mathrm{~B}$ & $2,4 \pm 0,02 \mathrm{C}$ & $2,6 \pm 0,02 \mathrm{D}$ & $3 \pm 0,03 \mathrm{E}$ \\
\hline
\end{tabular}

The differences between abdominal urosternites of males and females have been reported in other studies on Chrysomelidae since Salt (1928), who verified that the females of the banana fruit-scarring beetle Colaspis hypochlora Lefèvre, 1878, are distinguished from males by a deeper notch in the last visible urosternite. In the Colorado potato beetle Leptinotarsa decemlineata (Say, 1824), Pelletier (1993) found that the males have the last visible urosternite compressed with its distal border truncated while the females have the border rounded. Adults of the eucalypt leaf beetle Metaxyonycha angusta (Perty, 1832) can be sexed by the morphological characteristics of their fifth abdominal urosternite (FERNANDES et al., 2005). The differences observed in the abdominal segments of $C$. lurida corroborate all these studies, then the dimorphism observed in male and female urosternites is useful to determinate the gender of these insects. According to Bartlet et al. (1999), differences in the antenna structure allow distinguishing male and female imagos of the cabbage stem flea beetle Psylliodes chrysocephala (Linnaeus, 1758). However, there is no sexual dimorphism in such characteristics in C. lurida.

In most species of insects, females have their body larger than males, which can be easily used for sex differentiation (FOX et al., 2003). In Bruchinae, it is a general rule that the females are wider than males (SAVALLI \& FOX, 1998), except in the genus Stator where the males are generally broader than females. Finally, according Fernandes et al. (2005), female imagos of $M$. angusta have their body larger than males, which is congruent with our result. 


\section{CONCLUSION}

The morphological differences observed in the comparison of male and female of C. lurida corroborate previous studies on dimorphism in Chrysomelidae. So the characteristics of the pronotum and elytras width, the urosternite structure as well as the larger size of the abdomen of the female are trustworthy to determinate the gender in this beetle species.

\section{ACKNOWLEDGEMENTS}

To R. Wills Flowers of the Florida A \& M University, Tallahassee, for identification of the beetle, C. Matrangolo for help with the picture and Norivaldo dos Anjos for laboratory facilities. JHCD acknowledges his research grant from CNPq.

\section{REFERENCES}

ANJOS, N.; MAJER, J.D. 2003.Leaf-eating beetles in Brazilian eucalypt plantations. School of Environmental Biology Bulletin, Perth, vol. 1, no. 23, p. 8-9.

ARNHOLD, A.; GONÇALVES, D., 2010. Ocorrência de Costalimaita lurida (Coleoptera: Chrysomelidae) em Eucalyptus spp. em Minas Gerais. Pesquisa Florestal Brasileira, Colombo, vol. 30, no.63, p.257-259.

BARTLET, E.; ROMANI, R.; WILLIAMS, I.H.; ISIDORO, N. 1999. Functional anatomy of sensory structures on the antennae of Psylliodes chrysocephala L. (Coleoptera: Chrysomelidae). International Journal of Insect Morphology and Embryology, Amsterdam, vol. 28, no. 4, p. 291-300.

BUTT, B.A.; CANTU, E. 1962. Sex Determination of Lepidopterous Pupae. United States: Department of Agriculture. Agricultural Research Service, Washington, 7 .

FERNANDES, L.C.; ANJOS, N.; SILVEIRA, R.D. 2005. Dimorfismo sexual em Metaxyonicha angusta (Perty, 1832) (Coleoptera: Chrysomelidae). Acta Scientiarum Biological Sciences, Maringá, vol. 27, no. 2, p. 125-127.

FOX, C.W.; DUBLIN, L.; POLLITT, S.J. 2003. Gender differences in lifespan and mortality rates in two seed beetle species. Functional Ecology, Danvers, vol. 17, no. 5, p. 619-626.

MAFIA, R.G.; MENDES, J.E.P.; CORASSA, J.N. 2014. Análise comparativa dos surtos e danos causados pelos besouros desfolhadores Costalimaita ferruginea (Fabricius, 1801) e Costalimata lurida (Lefévre, 1891) (Coleoptera: Chrysomelidae) em plantios de eucalipto. Revista Árvore, Viçosa, vol. 28, no. 5, p. 829-836.

MARSARO-JÚNIOR, A.L.M.; PEREIRA, P.R.V.S.; PAIVA, W.R.S.C. 2006. Ocorrência de Costalimaita ferruginea (Coleoptera: Chrysomelidae) em citros no estado de Roraima. Embrapa Roraima, Boa Vista, 2 p. Comunicado Técnico, no. 10.

MELLINI, E. 1973. Sul riconoscimento esterno del sesso negli stadi preimmaginali degli insetti. Bollettino dell'Istituto di Entomologia della Università di Bologna, Bolonha, vol. 30, no. 1, p. 265-287.

PELLETIER, Y., 1993. A method for sex determination of the Colorado potato beetle pupa, Leptinotarsa decemlineata. Entomological News, Los Angeles, vol. 104, no. 1, p.140-142. 
SALT, G.A., 1928. Study of Colaspis hypochlora, Lefèvre. Bulletin of Entomological Research, Canterbury, vol. 19, no. 1, p. 295-308.

SAVALLI, U.M.; FOX, C.W. 1998. Sexual selection and the fitness consequences of male body size in the seed beetle Stator limbatus. Animal Behaviour, Nottingham, vol.55, no.2, p. 473483.

VILELA, E.F.; DELLA LUCIA, TMC. 2001. Feromônios de Insetos: Biologia, Química e Aplicação, 2da ed., Ribeirão Preto: Holos. 206 p.

WEBER, R.G. 1976. Sexing the elm leaf beetle, Pyrralta luteola (Coleoptera: Chrysomelidae). Annals of the Entomological Society of America, Lanham vol. 69, no. 2, p. 217-218.

Received in: January 21, 2019

Accepted in: April, 17, 2019 